CHAPTER 13:

\title{
Strengthening Connections Between Research, Policy, and Practice in Norwegian Civic and Citizenship Education
}

\author{
Heidi Biseth, Idunn Seland, and Lihong Huang
}

\begin{abstract}
In this chapter, we introduce recent education reforms in civic and citizenship education in Norway. We conducted an extensive literature review of relevant Norwegian published studies since 2000 , providing a broad overview of the variety of studies undertaken with the aim to strengthen the connections between research, policy, and practice in this field. This investigation of IEA's International Civic and Citizenship Education Study (ICCS) in the Norwegian policy documents, confirms the impression of civic and citizenship education studies having a substantial influence on the educational agenda in Norway.
\end{abstract}

\section{Introduction}

The Norwegian education system is designed to promote democracy together with values such as equality, solidarity, and human rights. Students are expected to share responsibilities for decisions and have the right to participate according to the Norwegian Education Act (Kunnskapsdepartementet 1998). In this chapter, we discuss Norwegian civic and citizenship education including the most recent reforms. Then we describe how Norwegian teachers are prepared to teach civic and citizenship education. As we did not find any summary of Norwegian publications on civic and citizenship education, we conducted a review from 2000. The chapter also describes how International Association for the Evaluation of Educational Achievement (IEA) International Civic and Citizenship Education Studies (ICCS) are presented in education discourse and appear to be influencing Norwegian policy.

Heidi Biseth was a member of the National Advisory Group for the ICCS 2016 in Norway, she also conducts research using IEA's Civic Education Study (CIVED) and ICCS data. Lihong Huang was the national research coordinator for ICCS 2016, and senior researcher Idunn Seland was an NRC research team member.

\section{Current Civic and Citizenship Education}

The last reform in Norwegian education took place in 2006, so the ICCS 2009 partially captures some of these alterations. The aim of the reform was to increase the achievements among all students as described by the Norwegian Ministry of Education and Research (Kunnskapsdepartementet 2020). Basic skills; orality, reading, writing, arithmetic, and digital skills, were introduced in all subjects and across all grades. Learning outcome-based education was introduced in addition to an increased local autonomy on how to organize the education. Two compulsory subjects are crucial in civic and citizenship education:

- Social studies (634 hours in total in grade 1-10, 168 hours in senior high school)

- Christianity, religion, philosophies of life, and ethics (580 hours in total in grade 1-10).

Heidi Biseth, Department of Culture, Religion and Social Studies, University of South-Eastern Norway, Drammen, Norway email: Heidi.biseth@usn.no

Idunn Seland, Youth Research Department of NOVA - Norwegian Social Research, Oslo Metropolitan University, Oslo, Norway

email: Idunn.Seland@oslomet.no

Lihong Huang, Youth Research Department of NOVA-Norwegian Social Research, Oslo Metropolitan University, Oslo, Norway

email: Ihuang@oslomet.no

(C) IEA International Association for the Evaluation of Educational Achievement 2021

B. Malak-Minkiewicz and J. Torney-Purta (eds.), Influences of the IEA Civic

and Citizenship Education Studies, https://doi.org/10.1007/978-3-030-71102-3_13 
In addition, most other subjects have some role in fulfilling the overall aims of civic or citizenship education, exemplified here by the described purpose of mathematics:

"Active democracy requires citizens who are able to study, understand and critically assess quantitative information, statistical analyses and economic prognoses. Hence mathematical competence is required to understand and influence processes in society" (Norwegian Directorate for Education and Training 2006).

Mathematics is eloquently described as a subject contributing to developing core civic traits, and complementary to other subjects in civic and citizenship education. Furthermore, the school is required to facilitate students' experience with examples of democratic participation and influence in everyday life, in the classroom, in the school, and in formal bodies like student councils.

Mikkelsen and Fjeldstad (2013) provided a thorough overview of civic and citizenship education in the Norwegian school system in the ICCS 2009 encyclopedia. Up until 2016 when ICCS was conducted, not much changed. However, a new national curriculum (Kunnskapsløftet 2020 - LK20) is implemented from August 2020 in which public health and life skills, democracy and citizenship, and sustainable development are the three crosscutting core themes considered important for addressing societal challenges. Each subject plan clearly addresses one, two, or all three of the crosscutting themes in specific ways. Democracy and citizenship move from a relatively peripheral position in the Education Act and the core curriculum to a central place difficult for headmasters and teachers to overlook.

\section{Teachers of Civic and Citizenship Education}

In the contemporary Norwegian education system, certain subjects play a key role in civic and citizenship education. Teachers of social studies and Christianity, religion, philosophies of life and ethics, as well as all qualified teachers of junior high schools, are capable of teaching the content prescribed for civic and citizenship education. Two programs exist to become a qualified teacher:

(1) a four-year teacher education program in which the candidate specializes in three or four subjects

(2) a bachelor's or master's degree relevant for the subjects the candidate is to teach and a year of teacher education including pedagogical theory and practice.

In the first program, candidates choose between qualifying for teaching at grade 1 through 7 or grade 5 through 10 . In the second program, the candidates qualify for teaching only grade 8 through grade 13. As of 2017, the first program became a full master's degree with first cohort graduating in 2022. The second program also changed in 2017, now requiring a master's degree for admission. This implies that all teachers graduating from 2022 onward will have a master's degree. The requirements also include more specialization in the subjects they expect to teach.

Professional development of current teachers is an ongoing process financed by the Ministry of Education and Research. Some initiatives are in-service education offered by teacher education institutions to advance the formal qualifications of current teachers to align with those of new teachers. However, local professional development projects are also funded. Municipalities decide what is needed in terms of competence development among their teachers. Then they link with a university or university college that can provide support. Currently, democracy and citizenship education are in increasing demand through such professional development projects as preparations for the new national curriculum from 2020.

\section{Norwegian Studies on Civic and Citizenship Education}

Norway participated in the IEA CIVED 1999, and in both ICCS 2009 and ICCS 2016. The major results from the CIVED 1999 study were that Norwegian students achieved above the international mean score in civic knowledge, varied scores on the civic engagement, whereas 
the country mean score was significantly higher than the international mean score on most dimensions of civic attitudes (Torney-Purta et al. 2001). The youth had some willingness to vote in future elections, but not to become active participants in representative democracy. Yet, they considered being active in other ways, engaging with issues of equal gender status, supportive of immigrants' rights, and trusting in political authorities and institutions (Mikkelsen et al. 2001; Mikkelsen et al. 2002; Torney-Purta et al. 2001). In ICCS 2009, similar results were reported (Mikkelsen et al. 2011; Schulz et al. 2010). Of the 24 participating countries in ICCS 2016, Norwegian youth was ranked as number five on the knowledge test with an average score of 564 , 47 points above the international average (Huang et al. 2017, p. 45). Interestingly, the difference in performance on the knowledge test between socioeconomic classes decreased from 47 points on ICCS 2009 to 35 points on ICCS 2016 (Huang et al. 2017, p. 67). The knowledge test showed a 9 point increasing gender difference favoring girls from ICCS 2009 to ICCS 2016 (Huang et al. 2017, p. 57). At the same time, a high level of trust existed toward political institutions but traditional media is weakened as a channel of political information (Huang et al. 2017; Schulz et al. 2018). The CIVED study and ICCS studies are, in a Norwegian context, complemented by several other studies on civic and citizenship education. A diversity of research objectives and approaches have been used, providing a more in-depth picture of practice in Norwegian civic and citizenship education.

Biseth has led a Norwegian team engaging in the independent Global Doing Democracy Research Project with the aim to develop a robust and critical democratic education curriculum and practice. The international project headed by Professor Paul Carr (Université du Québec en Outaouais, Canada) and Professor David Zyngier (Monash University, Australia) had an outreach to all continents. The questionnaire was adapted to each country and distributed in schools (e.g. Carr et al. 2012; Lund and Carr 2008). The Norwegian study was entitled Democracy in everyday life. The sample was recruited from teacher educators and student teachers as this is considered an under-investigated population with profound influence on practices of future teachers. The Norwegian team members, Wistrøm and Madsen (2018), published on a small portion of the sample of student teachers $(n=18)$, all in the subject of science. They argued that skills and experiences in the school subjects of natural science and democratic skills share common characteristics including critical thinking, the role of inquiry and evidence, and the capability to engage with public discourse or debate. These are all characteristics expected to be developed through the Norwegian education system and needed by a democratic citizenry (Kunnskapsdepartementet 1998). The researchers explored whether student teachers could identify connections between the systematic and critical procedures in natural science and democratic practices, concluding that students did not make this connection, rather understanding democracy solely as a political system (Wistrøm and Madsen 2018, p. 18). Eriksen (2018), also part of the project Democracy in everyday life, investigated which teaching practices student teachers in social studies associate with democratic education (n=81). "Students' participation" was the most prominent and appears a core concept in their views of democratic education. This includes students having their voice heard through voting in the classroom or through organized or more informal discussions (Eriksen 2018). In an unrelated study, student teachers were asked about promoting civic engagement through their own teaching. Biseth et al. (2018) corroborate that many had a superficial understanding of democracy as limited to a political system. Although many student teachers highlighted rights and freedoms, usually as human rights, as part of how we live together in a democracy, this was not visible in how they designed their teaching and learning activities.

These results on student teachers align with another publication in the Democracy in everyday life study focusing on about 150 teacher educators' understandings and descriptions of their practices related to democracy and democratic education (Biseth and Lyden 2018). The overwhelming majority of respondents reported encouraging student teachers to take part 
in formal participatory structures at the university level such as Students' Council; this meant promoting democratic engagement through formal political structures. Additionally, discussion was the predominant classroom activity used by teacher educators to prepare future teachers for democratic actions. The authors argue that several teacher educators in this study displayed an understanding of democracy that was more advanced than the weak understanding found in previous studies. However, it seemed as if teachers' understanding did not translate into their learning and teaching activities. For example, $95 \%$ of the respondents assess social justice as a core element of democracy, yet practices related to social justice was often considered to be beyond the mandate of a teacher educator. The few that addressed it limited this to create an inclusive community of learners across socioeconomic, racial, and gender lines. The absence of fighting for social justice issues such as gender equality, combating racism, or how to address sustainable development for all in the reported teaching practices, is interesting. If these selfreported practices carry reliability, teacher educators in this study seem to limit the tools future teachers have at their disposal for conducting democratic civic and citizenship education.

Beyond participation in international studies, Norwegian scholars have conducted research on democracy and citizenship education from several perspectives as will be clear in the following review. Many of these studies, especially from the early 2000s, are published only in Norwegian. IEA civic studies are mentioned in the literature review of several of these studies. Other studies are focused on schools from a policy perspective, and from teachers' and students' viewpoints. Some scholars have a political science orientation, investigating political organization, political socialization, or political participation as core democratic elements (e.g., Solhaug 2003; Børhaug 2007a, 2007b). Researchers with a background in teacher education have an approach focusing on civic and citizenship education within several school subjects.

Stray (2010) conducted a discourse analysis of Norwegian education policy and the national curriculum and compared this within-country discourse with international discourses on democracy and citizenship education. Stray argues that because of the 2006 education reform, democracy and citizenship were given less priority replaced by a focus on basic skills and core subjects. The fact that Norwegian students scored high on knowledge in the CIVED study may have given the impression that Norwegian schools are performing so well that little new attention is needed. This has provided an excuse for politicians and educators to move their focus away from democracy and civic education. In other words, democracy and democratic values may be seen as intrinsic to Norwegian schools, and, by extension, to the Norwegian population. Stray's conclusions are worrying, particularly when looking into data from other parts of CIVED showing, for example, that Norwegian students are considerably less likely than those in most of the other 27 countries to believe that it is important for adult citizens to engage in conventional political behavior such as voting or following political issues in the media (Torney-Purta et al. 2001, p. 82).

Using data from a national survey in 2002, which included more than 11,000 Norwegian youth aged 13-19, Lauglo and Øia (2008) reported on political socialization and political participation. This study was inspired by several factors, including an initiative of the OECD Centre for Educational Research and Innovation (CERI) entitled Outcomes of Learning and using results from the IEA civic education studies from 1971, 1999, and 2000. They concluded that the single most important education predictor of civic engagement of Norwegian high school students is whether young people hope and plan to progress to higher education.

Some other researchers have found that the role of education has less pronounced effects on the promotion of civic competence and engagement. Solhaug (2003) investigated civic competence among students in six Norwegian senior high schools in two regions of the country. His quasiexperimental study with 1,735 participants found that parents' educational background, interest in politics, and social engagement had significant impact on the student's civic competence. The schools' efforts had varied impacts depending on teachers' level of engagement and on students' 
enrollment in vocational or academic tracks. When the impact depends on individual teachers, development of civic competence can be vulnerable within the school system.

Embedded in the Norwegian Education Act (§ 11-2) is the belief that student councils are both a democratic hallmark of Norwegian education and a way of engaging Norwegian students in democratic political activities. The Act explicitly commits schools to democratic ways of planning, teaching, and organizing their activities. Børhaug (2007a, 2007b) investigated political education and asked the provocative question, "Are Norwegian student councils democratic?" (2007a, p. 27). In his empirical study of five junior high schools, he argues for two criteria to answer these questions: 1) student councils feeling free to engage in considering a broad range of issues they themselves see as important, and 2) student councils having an actual power base, not only the ability to simulate engagement in an imitation of democracy. Børhaug found that neither of these criteria were fulfilled, and what is labelled as democracy by the school does not really qualify as democratic activity. Biseth (2012) argues in the same vein, based on a study of democracy in multicultural school environments, claiming that students are socialized through what only appears to be a formal democracy. The students, rather, learn that their ability to act is strictly limited, their engagement unlikely to prove fruitful, and their achievements relate to minor issues allowed by the headmaster (usually related to social activities at school). One might ask whether the ambition of achieving democratic education through student councils accomplishes the intended aim in practice.

Furthermore, Solhaug and Osler (2018) argue that intercultural empathy constitutes a characteristic of an inclusively oriented citizen; they examined how 1,006 students across junior and senior high schools display this civic characteristic. There were substantial differences between boys' and girls' intercultural empathy (echoing a finding across the IEA civic education studies). Intercultural empathy was measured using expression of empathy, empathetic awareness, acceptance of cultural difference, and empathetic perspective taking. Students' understanding of cultural diversity predicted intercultural empathy. The school variables explored in this study to identify ways to support students' intercultural empathy showed limited associations with intercultural empathy outcomes. Yet, the authors suggest school practices supporting inclusive citizenship that promotes open dialogue and discussions. A comparative study conducted by Huang and Biseth (2016) concluded differently. Using Scandinavian student data from ICCS 2009 on the measures of open classroom climate (seven items that ask students how often they experience each of these seven teaching practices during regular lessons), the authors investigated how each practice contributed to increased students' civic knowledge achievement. Only students with high civic knowledge achievement were included in the analysis. The authors compared the strength of each of the classroom practices for its correlation with civic knowledge achievement by applying logistic regression (i.e., estimating the effect of each of these classroom practices on the probability of students becoming high achievers of civic knowledge). Practices such as "Teachers encourage students to make up their own minds" and "Students bring up current events" seem to increase the odds of high achievement of civic knowledge. The classroom practice where "Teachers encourage students to discuss the issue with people having different opinions," however, is the one teaching practice that appears to decrease students' odds of becoming high achievers in this Norwegian sample.

Several national studies on civic and citizenship education make suggestions on integrating these topics into several school subjects. Mathé (2016) focusing on social studies, investigated 16-yearold students' understanding of the concept of democracy $(N=23)$. Students primarily expressed a liberal understanding of democracy, focusing on voting in elections as the main characteristic. Mathé argues that teacher educators in social studies should engage actively in discussing and defining core concepts with their student teachers and develop further opportunities for understanding modes of democratic participation. 
Madsen and Biseth (2014b) edited a volume on democracy and citizenship education in school, illustrating how research on civic and citizenship education can be made hands on for teacher educators, student teachers, and teachers. Osler (2014) contributed a chapter on national and international perspectives on identity, democracy, and diversity, discussing the place of human rights and the role of the Council of Europe's Treaty on Human Rights Education and Citizenship Education. In the volume's section on general themes, Dahl (2014) provides a historical perspective on school democracy in Norway. He entitles this "a slow revolution" in democracy. Formative assessments at school can be used to enhance democracy, according to Bueie and Burner (2014). Stenshorne and Ballangrud (2014) argue that school management can use local professional development to promote democratic engagement by the school staff. Madsen and Biseth (2014a) report using social media in civic education. In the subject-specific section of the volume, researchers analyze various aspects of civic and citizenship education conducted within the subjects of Norwegian (Gjerstad 2014; Rustand 2014), social studies (Jenssen 2014; Sletvold 2014), mathematics (Madsen et al. 2014), religion (Valen-Sendstad 2014), science (Madsen and Strande 2014), and foreign language education (Heggernes 2014). There is a clear democratic mandate in the Norwegian Education Act intended to have ramifications for the teaching of every school subject. To be realistic, all the contributions above underline how civic education has the potential to be a significant component of practices in schools, but it depends on individual teachers and school leaders as to whether democracy and citizenship are included in curricula and school practices. To give one example of enhancing civic education school leaders have decided to work systematically for the prevention of racism, group-based hostility, and antidemocratic attitudes through the DEMBRA ${ }^{1}$ project (www.dembra.no/en).

In addition to the national report from ICCS 2016 (Huang et al. 2017), several articles have been published using student data in a special issue in the Norwegian Journal of Youth Research. Hegna, Ødegård, and Seland (2018) discuss the significance of democratic knowledge and fundamental processes of socialization in developing an active citizenship among Norwegian youth. Ødegård and Svagård (2018) argue that democratic knowledge does not automatically lead to political participation and investigates which factors have the most significance for political mobilization of youth. Based on data from ICCS 2009 and ICCS 2016, Hegna (2018a) addresses the question as to whether students from higher socioeconomic classes are becoming substantially more politically engaged than students from other socioeconomic classes. Again, comparing data from 2009 and 2016, Hegna (2018b) investigates changes in youths' attitudes towards civic rights. Stray and Huang (2018) consider the relation between youths' democratic knowledge and their acceptance of religious authorities in society, basing their study on ICCS 2009 and 2016 data. Seland and Huang (2018) take as a point of departure the fact that youth scoring high in the ICCS 2016 knowledge test also have high grades in subjects such as social studies, Norwegian, mathematics, and English and invokes the concept of literacy. The purpose of the analysis is to increase the understanding of connections between what students are expected to learn about democracy in school and their results on the knowledge test. Huang et al. (2018) compare data from Denmark, Norway, and Sweden to describe the trust Scandinavian youth have in institutions and interpersonal relationships, and their perspectives on future labor opportunities.

Furthermore, a special issue of the Nordic Journal of Comparative and International Education on ICCS 2016 data from teachers was published. Sætra and Stray (2019a) examined how social studies teachers' say they interpret and use different parts of the curriculum to teach for democracy. They also explored the kind of citizen that teachers hope to educate (Sætra and Stray 2019b). Hu and Huang (2019) conducted a comparative study of results from Norway, Sweden, South Korea, and Taiwan, examining teachers' professional development in terms of content

1 DEMBRA = Demokratisk beredskap mot rasisme og antisemittisme (Democratic preparedness against racism and antisemitism). 
knowledge and teaching methods, their sense of preparedness in teaching practice of civic and citizenship education. They investigated how these variables were associated with students' experience of classroom climate. Eriksen and Huang (2019) did a comparative analysis of ICCS 2016 data from Denmark, Finland, Norway, and Sweden examining the association between the school administration's awareness of bullying among their pupils, student reports of bullying, and the measures in place at schools in each country. Cheah and Huang (2019) investigate how practices undertaken to implement environmental citizenship education in Nordic schools are associated with the behaviors and attitudes of students and their future intensions to address environmental issues.

These numerous academic publications provide evidence of substantial interest in the ICCS studies among Norwegian educational researchers. In addition, Norwegian researchers are preoccupied with a range of themes within civic and citizenship education, particularly on how this plays out in the education sector, ranging from policy level, through teacher education to implementation in schools and classrooms. The studies not based on the ICCS studies complement and nuance the picture by going into more details on other aspects than ICCS. However, despite the well-established democracy in Norway, an almost unison voice is raised among the researchers stressing the need of even further growth and development in civic and citizenship education throughout all education levels and across subjects.

\section{Presence of ICCS Studies in Education Discourse, and their Influences in Norway}

In this section, we examine policy documents at the state level between 1999 and 2019 to determine whether, and how, the IEA's civic and citizenship studies have impacted policy formation for primary schools, high schools, and teacher education in Norway during this period. The document search was conducted through the website of the Norwegian parliament, www. stortinget.no, and complemented by a search for public reports in the series Norges offentlige utredninger ( $\mathrm{NOU}$ ) via the website of the Norwegian Ministry of Education and Research. NOUs are research, policy, and legal reviews prepared by public committees for subsequent government white papers or bills. We searched the websites for the abbreviations "CIVED"/"CIVIC"2 and "ICCS," which resulted in a sample of 22 documents, including parliamentary committee reports and minutes from parliamentary debates. We then searched the parliament's website for the keyword "demokrati" (democracy), specified to documents tagged with the keyword "undervisning" (education), resulting in a sample of seven documents not included in the first search.

The majority of these 29 documents were either written by or commissioned for the Norwegian Ministry of Education and Research (Kunnskapsdepartementet), or by the parliamentary committee responsible for education i.e., the committee for Church, Education and Research (kirke-, undervisnings- og forskingskomiteen). However, our search also yielded two government white papers referencing the CIVED/ICCS studies written by the Ministry of Finance (Finansdepartementet) and the Ministry of Trade and Fisheries (Nærings- og fiskeridepartementet), respectively, and one NOU written to the Ministry of Children and Equality. The first white paper points to the decreasing social gap in Norwegian students' democratic knowledge as demonstrated in the ICCS 2016 (Finansdepartementet 2019). The second white paper briefly comments on how results from the ICCS 2009 were made relevant to the Nordic Council of Ministers during Norway's presidency, resulting in a Nordic teacher educators' conference on democratic values (Nærings- og fiskeridepartementet 2013). In NOU 2008: 6 (Barne- og familiedepartementet 2008), a public committee refers to Norwegian students' attitudes towards gender equality measured in the CIVED study from 1999. In all, we found references to four

2 Our document search showed that IEA CIVED in 1999 has frequently been abbreviated "CIVIC" at Norwegian state level. 
academic publications in the total document sample. These are Fjeldstad et al. (2011), Fjeldstad et al. (2010), Mikkelsen et al. (2002), and Mikkelsen et al. (2001).

In order to conduct a closer document analysis, we let the search engine highlight the actual keyword (CIVED; CIVICS; ICCS; demokrati; undervisning), then copied the entire paragraph containing the keyword(s) from the policy documents into a separate Word file. By reviewing these paragraphs in their chronological order, we first detected, then coded for different contexts when the documents mentioned the CIVED/ICCS studies.

As demonstrated by Stray (2010), a considerable number of references to the CIVED/ICCS studies are in documents referring to the development of the Norwegian national quality assessment system in education, starting with NOU 2002: 10 (Kunnskapsdepartementet 2002). The national system of quality assessment represents our first main category of contexts for mentioning of the CIVED/ICCS studies. Particularly in the documents following the educational reform of 2006, the CIVED/ICCS are listed along with other international studies such as OECD's PISA and IEA'S TIMSS, PIRLS, and TEDS-M ${ }^{3}$ that benchmark Norwegian students and engage Norwegian educational authorities in an ongoing debate on quality in education (Kunnskapsdepartementet 2003; Kunnskapsdepartementet 2004; Kunnskapsdepartementet 2008; Kunnskapsdepartementet 2009b; Kunnskapsdepartementet 2013). However, none of the Norwegian results from the IEA studies on civic and citizenship education sparked much discussion in the public discourse. Instead, the curriculum reform in 2006 was heavily influenced by the relatively low achievements of Norwegian students in PISA 2003 (OECD 2004). Consequently, educational policy and research shifted focus towards teaching and learning quality in reading, mathematics, and science, based on competence aims in the entire basic education system in Norway, and few civic teachers have systematic education in didactics on civic subjects (Hu and Huang 2019; Mikkelsen and Fjeldstad 2013). Nevertheless, the overarching focus on democratic citizenship in the national core curriculum has remained the same since 1997. Hence, civic education is considered a key element of Norwegian school, at least in public pronouncements (Biseth 2009). However, democratic citizenship is only articulated in the specific subjects to a limited degree in the 1997 and 2006 reforms.

We also find government documents from this period that underline the importance of democracy and what Mikkelsen and Fjeldstad (2013, p. 317) refer to as "a fundamental value of society and consequently the common ground of education." This constitutes our second context category in the document analysis, although documents mentioning these features of democratic education do so without referring to the CIVED/ICCS studies. In these documents, "democracy" more or less equals "human rights" and civic participation based on democratic citizenship, which is in line with the traditional rendering of the concept in Norwegian education (Kunnskapsdepartementet 2009c; Kunnskapsdepartementet 2017). Government white papers mentioning democracy and teacher education are found in this category (Kunnskapsdepartementet 2009b). The revision of the preamble to the Education Act in 2008 (Kunnskapsdepartementet 2007) also contains several occurrences of the word "democracy," but it places this concept within the framework of the pedagogical and philosophical tradition of Bildung. ${ }^{4}$ This particular contextualization of "democracy" represents a sharp contrast to the way that "democracy" is used as a benchmark in documents referring to the IEA studies. This contrast further illustrates an ongoing debate in

3 PISA = Programme for International Student Assessment, TIMSS = Trends in International Mathematics and Science Study, PIRLS = Progress in International Reading Literacy Study, TEDS-M = Teacher Education and Development Study in Mathematics.

4 Bildung (German) is a concept deriving from continental and particularly German philosophy, meaning a creative process where a person shapes her own actions and cultural surroundings in order to attain a morally, ethically and aesthetically more advanced form of life (Siljander and Sutinen 2012, pp. 3-4). Bildung has no direct English equivalent, but the term "liberal education" is sometimes used to translate the same concept. However, the Swedish translation bildning and the Danish/Norwegian dannelse remain strong in Nordic pedagogy and educational discourse to this day. 
Norway about how learning outcomes and competences should be measured by standardized tests (Mikkelsen and Fjeldstad 2013).

We see in the documents how a combination of "democracy" understood as Bildung and references to the impact of the CIVED/ICCS studies on Norwegian policy formation become more evident after ICCS 2009. The first example is a white paper on junior high school (Kunnskapsdepartementet 2011) concerning a minor curriculum revision of 2013 affecting student councils (also see Kunnskapsdepartementet 2013). In the latter document, committee members use benchmarks from ICCS to back their more normative Bildung-based deliberations on the general value of school as the main site for democratic learning. These two different conceptual strands of "democracy" in Norwegian policy documents for education seem to merge in the national curriculum reform, to be implemented from August 2020 (Kunnskapsdepartementet 2015). This curriculum reform prescribes democracy and citizenship as one of three crosscutting themes in education, jointly with public health and life skills and sustainable development. First, this implies that democracy and citizenship are considered core values of Norwegian education. Second, the new curriculum mentions developing democratic competence as an aim for students. The education system is expected also to ensure a school environment in which students have experiences with what active participation in a democratic community entail. Additionally, educators are expected to foster citizens who can contribute to further developing democracy, making it more robust and sustainable. In other words, it is no longer sufficient to socialize students into the current democratic system; they have to become agents for improving democracy (cf. Biesta 2011; Westheimer 2015).

What we see in policy documents from the 20 years that have passed since Norway joined the CIVED study in 1999 is that the idea of democracy and civic and citizenship education fall into two distinctive categories, which could be said to evolve as two strands. The first strand utilizes the IEA studies as benchmarks for educational quality, whereas the other strand continues the understanding of democracy as a core educational value that cannot be fully measured through standardized tests. After ICCS 2009, we detect in the documents an alignment of these two conceptualizations: new educational efforts for civic and citizenship education refer to both the IEA studies and to democratic Bildung, combining these as competence aims for democratic learning.

\section{Conclusion}

It is evident that the ICCS studies have begun to have an impact at the education policy level in Norway, although they have sparked little public debate and yet have had little direct influence on teacher education and school practices. We observe connections between nationally based research on democratic citizenship and international studies such as the ICCS, specifically those targeting the fields of teacher education and school practices. We regard these trends as welcome parts of a national effort to strengthen the connections between policy, research, and practices in the education system to encourage the development of active democratic citizens.

\section{References}

Barne- og familiedepartementet (2008). NOU 2008: 6. Kjønn og lønn. Fakta, analyser og virkemidler for likelønn [Report No. 2008: 6. Gender and salary. Facts, analyses, and measures for equal wages]. Oslo, Norway: Ministry of Children and Families.

Biesta, G. J. J. (2011). Learning democracy in school and society: Education, lifelong learning, and the politics of citizenship. Rotterdam, the Netherlands: Sense Publishers.

Biseth, H. (2009). Democracy and education in a multicultural Scandinavia: what mandate is designated to educators? Intercultural Education, 20(3), 243-254. https://doi.org/10.1080/14675980903138590 
Biseth, H. (2012). Citizenship education in Scandinavian multicultural schools: A comparative study of students' and teachers' perceptions. Citizenship Teaching and Learning, 7(1), 71-88.

Biseth, H., \& Lyden, S. C. (2018). Norwegian teacher educators' attentiveness to democracy and their practices. International Journal of Learning, Teaching and Educational Research, 17(7), 26-42. https://dor.org /10.26803/ijlter.17.7.2.

Biseth, H., Madsen, J., \& Christensen, I. R. (2018). Student teachers promoting democratic engagement using social media in teaching. Nordic Journal of Comparative and International Education, 2(4), 37-52. https://doi/org/10.7577/njcie.2796.

Bueie, A., \& Burner, T. (2014). Demokratisk vurdering i skolen. In J. Madsen, \& H. Biseth (Eds.), Må vi snakke om demokrati? Om demokratiske praksiser i skolen (pp. 83-100). Oslo, Norway: Universitetsforlaget.

Børhaug, K. (2007a). Mission impossible? School level student democracy. Citizenship, Social and Economics Education, 7(1), 26-41. https://doi.org/10.2304/csee.2007.7.1.26.

Børhaug, K. (2007b). Oppseding til demokrati: Ein studie av politisk oppseding i norsk skule. (Dr. philos.). Bergen, Norway: University of Bergen.

Carr, P. R., Zyngier, D., \& Pruyn, M. (Eds.). (2012). Can educators make a difference? experimenting with, and experiencing, democracy in education. Charlotte, NC: International Age Publishing.

Cheah, S. L., \& Huang, L. (2019). Environmental citizenship in a Nordic civic and citizenship education context. Nordic Journal of Comparative and International Education (NJCIE), 3(1), 88-104. https://doi.org/ 10.7577/njcie.3268

Dahl, A. G. (2014). Skoledemokrati - en langsom revolusjon. In J. Madsen, \& H. Biseth (Eds.), Må vi snakke om demokrati? Om demokratiske praksiser i skolen? (pp. 66-81). Oslo, Norway: Universitetsforlaget.

Eriksen, I. M., \& Huang, L. (2019). Different reports of school bullying by students, teachers and principals: A Nordic comparison. Nordic Journal of Comparative and International Education, 3(1), 51-68. https://doi.org/ 10.7577/njcie.3332

Eriksen, K. G. (2018). Bringing democratic theory into didactical practice: Concepts of education for democracy among Norwegian pre-service teachers. Interchange. A Quarterly Review of Education, 1-17. https://doi.org/10.1007/s10780-018-9332-7.

Finansdepartementet. (2019). Meld. St. 13 (2018-2019). Muligheter for alle - Fordeling og sosial bærekraft [Report No. 13 (2018-2019). Opportunities for all - distribution and social sustainability]. Oslo, Norway: Ministry of Finance.

Fjeldstad, D., Mikkelsen, R., \& Lauglo, J. (2011). Morgendagens samfunnsborgere. Norske ungdomsskoleelevers prestasjoner og svar på spørsmål i den internasjonale demokratiundersøkelsen ICCS. Oslo, Norway: Universitetet i Oslo, Institutt for lærerutdanning og skoleforskning.

Fjeldstad, D., Mikkelsen, R., \& Lauglo, J. (2010). Demokratisk beredskap. Kortrapport om norske ungdomsskoleelevers prestasjoner og svar på spørsmål i den internasjonale demokratiundersøkelsen International Civic and Citizenship Education Study (ICCS 2009). Oslo, Norway: Universitetet i Oslo, Institutt for lærerutdanning og skoleforskning.

Gjerstad, M. (2014). Demokratisk kompetanse gjennom skriftlige ferdigheter i norskfaget. In J. Madsen, \& H. Biseth (Eds.), Må vi snakke om demokrati? Om demokratiske praksiser i skolen (pp. 217-235). Oslo, Norway: Universitetsforlaget.

Heggernes, S. L. (2014). Demokratisk og interkulturell kompetanse i fremmedspråkopplæringen. In J. Madsen, \& H. Biseth (Eds.), Må vi snakke om demokrati? Om demokratiske praksiser i skolen (pp. 255-270). Oslo, Norway: Universitetsforlaget.

Hegna, K. (2018a). Endringer i samfunnspolitisk engasjement og deltakelse blant ungdom 2009 - 2016 : $\varnothing$ kte sosiale forskjeller og polarisering? Tidsskrift for ungdomsforskning/Norwegian Journal of Youth Research, 18(1), 51-74.

Hegna, K. (2018b). Har ungdomsholdninger til medborgerrettigheter endret seg fra 2009 til 2016 ? Betydningen av kjønn og familiebakgrunn for holdninger til kjønnslikestilling, innvandreres og etniske minoriteters rettigheter. Tidsskrift for ungdomsforskning/Norwegian Journal of Youth Research, 18(1), 75-97.

Hegna, K., Ødegård, G., \& Seland, I. (2018). Ungt medborgerskap: Kunnskap, mobilisering og deltakelse. Tidsskrift for ungdomsforskning/Norwegian Journal of Youth Research, 18(1), 7-27.

Hu, A., \& Huang, L. (2019). Teachers' professional development and an open classroom climate. Nordic Journal of Comparative and International Education, 3(1), 33-50. https://doi.org/10.7577/njcie.2871. 
Huang, L., \& Biseth, H. (2016). Openness in Scandinavian classrooms: Student perceptions of teaching practices and high achievers of civic knowledge. Creative Education, 7(5), 713-723. https://doi.org/ 10.4236/ce.2016.75075

Huang, L., Bruun, J., Lieberkind, J., \& Arensmeier, C. (2018). Nye tall om ungdom: Skandinaviske ungdommers tillit til samtid og framtid. Tidsskrift for ungdomsforskning/Norwegian Journal of Youth Research, 18(1), 146-165.

Huang, L., Ødegård, G., Hegna, K., Svagård, V., Helland, T., \& Seland, I. (2017). Unge medborgere. Demokratiforståelse, kunnskap og engasjement blant 9.-klassinger i Norge: The International Civic and Citizenship Education Study (ICCS) 2016. Oslo, Norway: NOVA-Høgskolen i Oslo og Akershus (HIOA).

Jenssen, L. L. (2014). Menneskerettighetsundervisning i samfunnsfag 8.-10. trinn. In J. Madsen, \& H. Biseth (Eds.), Må vi snakke om demokrati? Om demokratiske praksiser i skolen (pp. 185-201). Oslo, Norway: Universitetsforlaget.

Kunnskapsdepartementet. (1998). Opplæringsloven. Oslo, Norway: Ministry of Education. https://www. regjeringen.no/contentassets/b3b9e92cce6742c39581b661a019e504/education-act-norway-withamendments-entered-2014-2.pdf

Kunnskapsdepartementet. (2002). NOU 2002: 10. Førsteklasses fra første klasse. Forslag til rammeverk for et nasjonalt kvalitetsvurderingssystem av norsk grunnopplæring [Report No. 2002:10. First-class from grade 1. Proposal for a framework on a national quality assessment system of Norwegian basic education]. Oslo, Norway: Ministry of Education and Research.

Kunnskapsdepartementet. (2003). NOU 2003: 16. I første rekke. Forsterket kvalitet i en grunnopplæring for alle [Report No. 2003: 16. In the front rank. Enhanced quality in a basic education for all]. Oslo, Norway: Ministry of Education and Research.

Kunnskapsdepartementet. (2004). St. meld. nr. 30 (2003-2004). Kultur for læring [White paper. 30 (20032004). Culture for learning]. Oslo, Norway: Ministry of Education and Research.

Kunnskapsdepartementet. (2007). NOU 2007: 6. Formål for framtida - Formål for barnehagen og opplæringen [Report No. 2003: 16. Purpose for the future - Objectives of the kindergarten and education]. Oslo, Norway: Ministry of Education and Research.

Kunnskapsdepartementet. (2008). St. meld. nr. 31 (2007-2008). Kvalitet i skolen [White paper. 31 (20072008). Quality in Education]. Oslo, Norway: Ministry of Education and Research.

Kunnskapsdepartementet. (2009a). St. meld. nr. 11 (2008-2009) Læreren. Rollen og utdanningen [White paper 11 (2008-2009). The teacher: the role and the traning]. Oslo, Norway: Ministry of Education and Research.

Kunnskapsdepartementet. (2009b). St. meld. nr. 14 (2008-2009). Internasjonalisering av utdanning [White paper 14 (2008-2009). Internationalization of education]. Oslo, Norway: Ministry of Education and Research. Kunnskapsdepartementet. (2009c). St. meld. nr. 44 (2008-2009). Utdanningslinja [White paper 44 (2008-2009). Education measures]. Oslo, Norway: Ministry of Education and Research.

Kunnskapsdepartementet. (2011). Meld. St. 22 (2010-2011). Motivasjon - mestring - muligheter. Ungdomstrinnet [White paper 22 (2010-2011). Motivation - mastering - opportunities. Junior high school]. Oslo, Norway: Ministry of Education and Research.

Kunnskapsdepartementet. (2013). Meld. St. 20 (2012-2013). På rett vei. Kvalitet og mangfold i fellesskolen [White paper 20 (2012-2013). On the right track. Quality and diversity in the comprehensive school system]. Oslo, Norway: Ministry of Education and Research.

Kunnskapsdepartementet. (2015). Meld. St. 28 (2016-2017). Fag - fordypning - forståelse. En fornyelse av Kunnskapsløftet [White paper 28 (2016-2017). Subject - specialization - comprehension. A renewal of the Curriculum Knowledge Promotion]. Oslo, Norway: Ministry of Education and Research.

Kunnskapsdepartementet. (2017). NOU 2018: 15. Kvalifisert, forberedt og motivert. Et kunnskapsgrunnlag om struktur og innhold i videregående opplæring [Report No. 2018: 15. Qualified, prepared, and motivated. A basis of knowledge on structure and content in senior high school]. Oslo, Norway: Ministry of Education and Research.

Kunnskapsdepartementet. (2020). Kunnskapsløftet. Oslo, Norway: Ministry of Education and Research. https://www.regjeringen.no/no/tema/utdanning/grunnopplaring/kunnskapsloftet/id534689/

Lauglo, J., \& Øia, T. (2008). Education and civic engagement among Norwegian youth. Policy Futures in Education, 6(2), 203-223. https://doi.org/10.2304/pfie.2008.6.2.203.

Lund, D. E., \& Carr, P. R. (Eds.). (2008). Doing democracy: Striving for political literacy and social justice. New York, NY: Peter Lang. 
Madsen, J., \& Biseth, H. (2014a). Demokratisk deltakelse og sosiale medier. In J. Madsen, \& H. Biseth (Eds.), Må vi snakke om demokrati? Om demokratiske praksiser i skolen (pp. 118-133). Oslo, Norway: Universitetsforlaget.

Madsen, J., \& Biseth, H. (Eds.). (2014b). Må vi snakke om demokrati? Om demokratisk praksis i skolen. Oslo, Norway: Universitetsforlaget.

Madsen, J., Gustavsen, T., \& Nylund, N. G. (2014). Matematikk med mening - et undervisningsopplegg med 8. klasse med fokus på brøk. In J. Madsen, \& H. Biseth (Eds.), Må vi snakke om demokrati? Om demokratiske praksiser i skolen (pp. 153-167). Oslo, Norway: Universitetsforlaget.

Madsen, J., \& Strande, A. L. (2014). Naturfag som læringsarena for demokrati. In J. Madsen, \& H. Biseth (Eds.), Må vi snakke om demokrati? Om demokratiske praksiser i skolen (pp. 202-216). Oslo, Norway: Universitetsforlaget.

Mathé, N. E. H. (2016). Students' understanding of the concept of democracy and implications for teacher education in social studies. Acta Didactica Norge, 10(2), 271-289. https://doi.org/10.5617/adno.2437.

Mikkelsen, R., Buk-Berge, E., Ellingsen, H., Fjeldstad, D., \& Sund, A. (2001). Demokratisk beredskap og engasjement hos 9. klassinger i Norge og 27 andre land: Civic Education Study Norge 2001. Oslo, Norway: Institutt for lærerutdanning og skoleutvikling, Universitetet i Oslo.

Mikkelsen, R., \& Fjeldstad, D. (2013). Norway. In J. Ainley, W. Schulz, \& T. Friedman (Eds.), ICCS 2009 encyclopedia: Approaches to civic and citizenship education around the world (pp. 313-321). Amsterdam, the Netherlands: International Association for the Evaluation of Educational Achievement (IEA).

Mikkelsen, R., Fjeldstad, D., \& Ellingsen, H. (2002). Demokratisk beredskap og engasjement hos elever i videregående skole i Norge og 13 andre land: Civic Education Study Norge 2002. Oslo, Norway: Institutt for lærerutdanning og skoleutvikling, Universitetet i Oslo.

Mikkelsen, R., Fjeldstad, D., \& Lauglo, J. (2011). Morgendagens samfunnsborgere: Norske ungdomsskoleelevers prestasjoner og svar på spørsmål i den internasjonale demokratiundersøkelsen ICCS. Oslo, Norway: Institutt for lærerutdanning og skoleutvikling, Universitetet i Oslo.

Norwegian Directorate for Education and Training. (2006). Curriculum for the common core subject of Mathematics. Oslo, Norway: Ministry of Education and Research. https://www.udir.no/kI06/MAT1-04/ Hele/Formaal?lplang=http://data.udir.no/kl06/eng

Nærings- og fiskeridepartementet. (2013). Meld. St. 50 (2012-2013). Nordisk samarbeid [White paper 50 (2012-2013). Nordic cooperation]. Oslo, Norway: Ministry of Trade and Fishery.

Organisation for Economic Co-operation and Development (OECD). (2004). Learning for tomorrow's world: First results from PISA 2003. Paris, France: OECD Publishing. https://doi.org/10.1787/9789264006416-en

Osler, A. (2014). Identitet, demokrati og mangfold i skoler: nasjonale og internasjonale perspektiver [Identity, democracy and diversity in schools: national and international perspectives]. In J. Madsen, \& H. Biseth (Eds.), Må vi snakke om demokrati? Om demokratiske praksiser i skolen (pp. 46-65). Oslo, Norway: Universitetsforlaget.

Rustand, K. A. (2014). Digital tekstkompetanse og demokrati i norskfaget. In J. Madsen, \& H. Biseth (Eds.), Må vi snakke om demokrati? Om demokratiske praksiser i skolen (pp. 135-152). Oslo, Norway: Universitetsforlaget.

Sætra, E., \& Stray, J. H. (2019a). Hva slags medborger? Nordic Journal of Comparative and International Education, 3(1), 19-32. https://doi.org/10.7577/njcie.2441

Sætra, E., \& Stray, J. H. (2019b). Læreplan og demokrati. Nordic Journal of Comparative and International Education, 3(1), 3-18. https://doi.org/10.7577/njcie.2440

Schulz, W., Ainley, J., Fraillon, J., Kerr, D., \& Losito, B. (2010). ICCS 2009 international report: Civic knowledge, attitudes, and engagement among lower secondary school students in 38 countries. Amsterdam, the Netherlands: International Association for the Evaluation of Educational Achievement (IEA).

Schulz, W., Ainley, J., Fraillon, J., Losito, B., Agrusti, G., Friedman, T. (2018). Becoming citizens in a changing world: IEA International Civic and Citizenship Education Study 2016 international report. Cham, Switzerland: Springer. https://doi.org/10.1007/978-3-319-73963-2

Seland, I., \& Huang, L. (2018). Literacy som aspekt ved norske elevers demokratikunnskap. Tidsskrift for ungdomsforskning/Norwegian Journal of Youth Research, 18(1), 123-145.

Siljander, P., \& Sutinen, A. (2012). Introduction. In P. Siljander, A. Kivelä, \& A. Sutinen (Eds.), Theories of Bildung and Growth. Connections and Controversies Between Continental Educational Thinking and American Pragmatism (Chapter 1, pp. 1-18). Rotterdam, the Netherlands: Sense Publishers. 
Sletvold, L. (2014). Fortellinger og varslere - betydningen av sivilt mot og sivil ulydighet for demokratiet. In J. Madsen \& H. Biseth (Eds.), Må vi snakke om demokrati? Om demokratiske praksiser i skolen (pp. 168-184). Oslo, Norway: Universitetsforlaget.

Solhaug, T. (2003). Utdanning til demokratisk medborgerskap. (Dr. polit.). Oslo, Norway: Institutt for lærerutdanning og skoleutvikling, Universitetet i Oslo.

Solhaug, T., \& Osler, A. (2018). Intercultural empathy among Norwegian students: an inclusive citizenship perspective. International Journal of Inclusive Education, 22(1), 89-110. https://doi.org/10.1080/13603 116.2017.1357768

Stenshorne, E., \& Ballangrud, E. (2014). Ledelsens utfordringer og muligheter i skolen som demokratisk organisasjon. In J. Madsen, \& H. Biseth (Eds.), Må vi snakke om demokrati? Om demokratiske praksiser i skolen (pp. 101-117). Oslo, Norway: Universitetsforlaget.

Stray, J. H. (2010). Demokratisk medborgerskap i norsk skole? En kritisk analyse. (Ph.D.). Oslo, Norway: University of Oslo.

Stray, J. H., \& Huang, L. (2018). Norske elevers demokratikunnskaper og aksept for religiøse autoriteter i samfunnet. Tidsskrift for ungdomsforskning/Norwegian Journal of Youth Research, 18(1), 98-122.

Torney-Purta, J., Lehmann, R., Oswald, H., \& Schulz, W. (2001). Citizenship and education in twenty-eight countries: Civic knowledge and engagement at age 14. Amsterdam, the Netherlands: International Association for the Evaluation of Educational Achievement (IEA).

Valen-Sendstad, Å. (2014). Religion, livssyn og etikk (RLE) som et demokratifag: pluralisme og demokratiske verdier. In J. Madsen, \& H. Biseth (Eds.), Må vi snakke om demokrati? Om demokratiske praksiser i skolen (pp. 234-254). Oslo, Norway: Universitetsforlaget.

Westheimer, J. (2015). What kind of citizen? Educating our children for the common good. New York, NY: Teachers College Press.

Wistrøm, Ø., \& Madsen, J. (2018). Democracy and science: two sides of the same coin? Nordisk tidsskrift for pedagogikk og kritikk, 4, 50-68. https://doi.org/10.23865/ntpk.v4.559

Ødegård, G., \& Svagård, V. (2018). Hva motiverer elever til å bli aktive medborgere? Tidsskrift for ungdomsforskning/Norwegian Journal of Youth Research, 18(1), 28-50.

Open Access This chapter is licensed under the terms of the Creative Commons Attribution-NonCommercial 4.0 International License (http://creativecommons.org/licenses/by-nc/4.0/), which permits any noncommercial use, sharing, adaptation, distribution and reproduction in any medium or format, as long as you give appropriate credit to the original author(s) and the source, provide a link to the Creative Commons license and indicate if changes were made.

The images or other third party material in this chapter are included in the chapter's Creative Commons license, unless indicated otherwise in a credit line to the material. If material is not included in the chapter's Creative Commons license and your intended use is not permitted by statutory regulation or exceeds the permitted use, you will need to obtain permission directly from the copyright holder.

\section{(ब) $\odot$}

